\section{Potential Photosynthetic Advantages of Cucumber (Cucumis sativus L.) Seedlings Grown under Fluorescent Lamps with High Red:far-red Light}

Toshio Shibuya ${ }^{1}$, Ryosuke Endo, Yuki Kitamura, and Yoshiaki Kitaya Graduate School of Life and Environmental Science, Osaka Prefecture University, Gakuen-cho, Naka-ku, Sakai, Osaka 599-8531, Japan

Nobuaki Hayashi

School of Life and Environmental Science, Osaka Prefecture University, Gakuen-cho, Naka-ku, Sakai, Osaka 599-8531, Japan

Additional index words. electron transfer rate, gross photosynthetic rate, light response curve, quantum yield of PSII ( $\left.\Phi_{\text {PSII }}\right)$, transplant production

\begin{abstract}
To evaluate the effect of fluorescent lamps with a high red:far-red (R:FR) light on the potential photosynthesis of transplants, we investigated the photosynthetic light responses of cucumber (Cucumis sativus $\mathrm{L}$.) seedlings grown under fluorescent lamps with high R:FR light $\left(\mathrm{FL}_{\mathrm{H}}\right)$ and compared them with the responses of the seedlings grown under metal-halide lamps (ML) that provided a spectrum similar to that of natural light and under a fluorescent lamp with low $R$ :FR light $\left(F L_{L}\right)$. The seedlings were grown under $F_{H}(R: F R=7.0), M L(R: F R=1.2)$, or $F_{L}(R: F R=1.1)$ at a photosynthetic photon flux density $(P P F D)$ of $350 \mu \mathrm{mol} \cdot \mathrm{m}^{-2} \cdot \mathrm{s}^{-1}$. The gross photosynthetic rate $\left(\mathrm{P}_{\mathrm{g}}\right)$, quantum yield of photosystem II $\left(\Phi_{\mathrm{PSII}}\right)$, and photosynthetic electron transfer rate (ETR) of the foliage leaves were then evaluated at $P P F D s$ ranging from 0 to $1000 \mu \mathrm{mol} \cdot \mathrm{m}^{-2} \cdot \mathrm{s}^{-1}$. The photosynthetic light response of $\mathrm{FL}_{H}$ seedlings was similar to those of sun leaves, and the responses of $M L$ and $F L_{L}$ seedlings were similar to those of shade leaves. The $P_{g}$, ETR, and $\Phi_{\text {PSII }}$ of $\mathrm{FL}_{\mathrm{H}}$ seedlings at $P P F D$ of $1000 \mu \mathrm{mol} \cdot \mathrm{m}^{-2} \cdot \mathrm{s}^{-1}$ was $1.38,1.32$, and 1.28 times, respectively, those of $\mathrm{ML}$ seedlings, and was 1.40, 1.23, and 1.22 times, respectively, those of $F_{L}$ seedlings. The $P_{g}$ was closely correlated with ETR in each treatment. $F L_{H}$ seedlings had thicker leaf and greater chlorophyll content per leaf area than $M L$ and $F L_{L}$ seedlings. The greater $P_{g}$ of $F L_{H}$ seedlings than in the other two groups of seedlings at high $P P F D$ was probably the result of the improved ETR resulting from physiological and morphological changes in response to the high R:FR light.
\end{abstract}

High-performance production systems unconstrained by weather conditions have recently been developed to produce high-quality transplants under artificial light (Kozai, 2007; Kozai et al., 2006). Seedlings grown under light provided by the fluorescent lamps used in these systems have less shoot elongation than those grown under natural light (Ohyama et al., 2003). The reduced shoot elongation seems to be the result of the high red to far-red ratios (R:FR) of typical commercial fluorescent lamps, which emit little FR irradiance. Elongation of plant shoots could be improved by increasing the FR content of the light from these lamps (Murakami et al., 1991). In natural ecosystems, shoot elongation and leaf expansion are increased and leaf thickness and chlorophyll content reduced by a reduction in the R:FR resulting from absorption of red irradiation by neighboring vegetation (Smith

Received for publication 15 Jan. 2010. Accepted for publication 24 Feb. 2010.

We thank Mr. Junki Komuro for his technical assistance in growing the plant materials.

${ }^{1}$ To whom reprint requests should be addressed; e-mail shibuya@envi.osakafu-u.ac.jp. and Whitelam, 1997). This morphological response is called shade avoidance and is used by plants to tolerate or avoid shading (Franklin, 2008). In contrast, the higher-than-natural R:FR of fluorescent lamps may improve adaptability to high irradiation levels because seedlings under such lamps show morphological responses that are inverse to shade avoidance. At high irradiation levels, leaves adapted to high irradiation (sun leaves) have greater photosynthetic light-use efficiency than shaded leaves (Lichtenthaler et al., 1981). If adaptation of seedlings to high irradiation could be improved by growth under fluorescent lamps, then the photosynthetic efficiency and consequent growth at high irradiation could be improved. However, photosynthetic acclimation to light at higher-than-natural $\mathrm{R}$ :FR has not been well investigated, although that at lower R:FR has been investigated in ecological science studies (Corré, 1983; Maliakal et al., 1999; Murchie and Horton, 1997; Sleeman and Dudley, 2001; Sleeman et al., 2002; Turnbull et al., 1993). To evaluate the effect of adaptation to fluorescent light with high R:FR light on the potential photosynthetic advantage of transplants, we investigated the photosynthetic light responses of cucumber (Cucumis sativus L.) seedlings grown under fluorescent lamps with high R:FR light and compared them with the responses of the seedlings grown under metal-halide lamps that provided a spectrum similar to that of natural light and under a fluorescent lamp with low R:FR light.

\section{Materials and Methods}

Expt. 1: Comparison of high red:far-red fluorescent lamps with metal-halide lamps. Cucumis sativus L. 'Hokushin' was sown in plastic pots ( $60 \mathrm{~mm}$ diameter, $55 \mathrm{~mm}$ height) containing vermiculite medium and then germinated in a chamber maintained at an air temperature of 26 to $28{ }^{\circ} \mathrm{C}$, a relative humidity of $60 \%$, and a photosynthetic photon flux density $(P P F D)$ of $250 \mu \mathrm{mol} \cdot \mathrm{m}^{-2} \cdot \mathrm{s}^{-1}$ under fluorescent lamps (FHF32EX-N-H; Panasonic Corp., Kadoma, Japan) with a light:dark photoperiod of 12:12 h. After the cotyledons had fully expanded, the seedlings were moved to growth chambers illuminated with fluorescent lamps with high R:FR light (FPL55EX-N; Panasonic Corp.) ( $\mathrm{FL}_{\mathrm{H}}$ ) or with metal-halide lamps (DR400/TL; Toshiba Lighting \& Technology Corp., Yokosuka, Japan) (ML) providing a spectrum similar to that of natural light. The $\mathrm{R}$ (wavelength 600 to $700 \mathrm{~nm}$ ):FR ( 700 to $800 \mathrm{~nm}$ ) of $\mathrm{FL}_{\mathrm{H}}$ was 7.0 and that of ML was 1.2. The spectrum of ML was similar to that of natural light, except that ML had strong peaks at wavelengths of 540 to $570 \mathrm{~nm}$ (Fig. 1). The spectra were measured by a spectrometer (BLK-CXR-SR; StellarNet Inc., Tampa, FL).

Nutrient solution (A-type recipe of Otsuka House Solution; Otsuka Chemical Co. Ltd., Osaka, Japan) was supplied to the bottoms of the pots continuously by standing the pots in a solution 5 to $10 \mathrm{~mm}$ deep. The composition of the solution in grams per $1000 \mathrm{~L}$ of tap water was: total nitrogen, 260; $\mathrm{P}_{2} \mathrm{O}_{5}, 120$; $\mathrm{K}_{2} \mathrm{O}, 405 ; \mathrm{CaO}, 230 ; \mathrm{MgO}, 60 ; \mathrm{MnO}, 1.5$; $\mathrm{B}_{2} \mathrm{O}_{3}$, 1.5; iron, 2.7; copper, 0.03; zinc, 0.09; and molybdenum, 0.03 . Electrical conductivity was $\approx 2.6 \mathrm{mS} / \mathrm{cm}$, and the $\mathrm{pH}$ value was $\approx 6.5$. The growth conditions were: air temperature 27 to $28{ }^{\circ} \mathrm{C}$, relative humidity $50 \%$, and PPFD $350 \mu \mathrm{mol} \cdot \mathrm{m}^{-2} \cdot \mathrm{s}^{-1}$ at the canopy surface with a light:dark photoperiod of 12:12 h. The PPFD at the canopy was maintained by adjusting the distance between the light sources and the plant canopy during the growing period. A water filter (20-mm depth) was placed under the ML to prevent increases in leaf temperature from the long-wave radiation from the ML.

After being grown for $8 \mathrm{~d}$ under $\mathrm{FL}_{\mathrm{H}}$ or $6 \mathrm{~d}$ under ML, sample seedlings from each treatment group were taken to measure the net photosynthetic rate $\left(\mathrm{P}_{\mathrm{n}}\right)$ and quantum yield of photosystem II photochemistry ( $\Phi_{\text {PSII }}$; Maxwell and Johnson, 2000). Because of the faster development of leaves under ML than under $\mathrm{FL}_{\mathrm{H}}, \mathrm{FL}_{\mathrm{H}}$ seedlings took $2 \mathrm{~d}$ longer to equal the growth stage of ML seedlings for measurement. The seedlings under each treatment had one full-expanded 

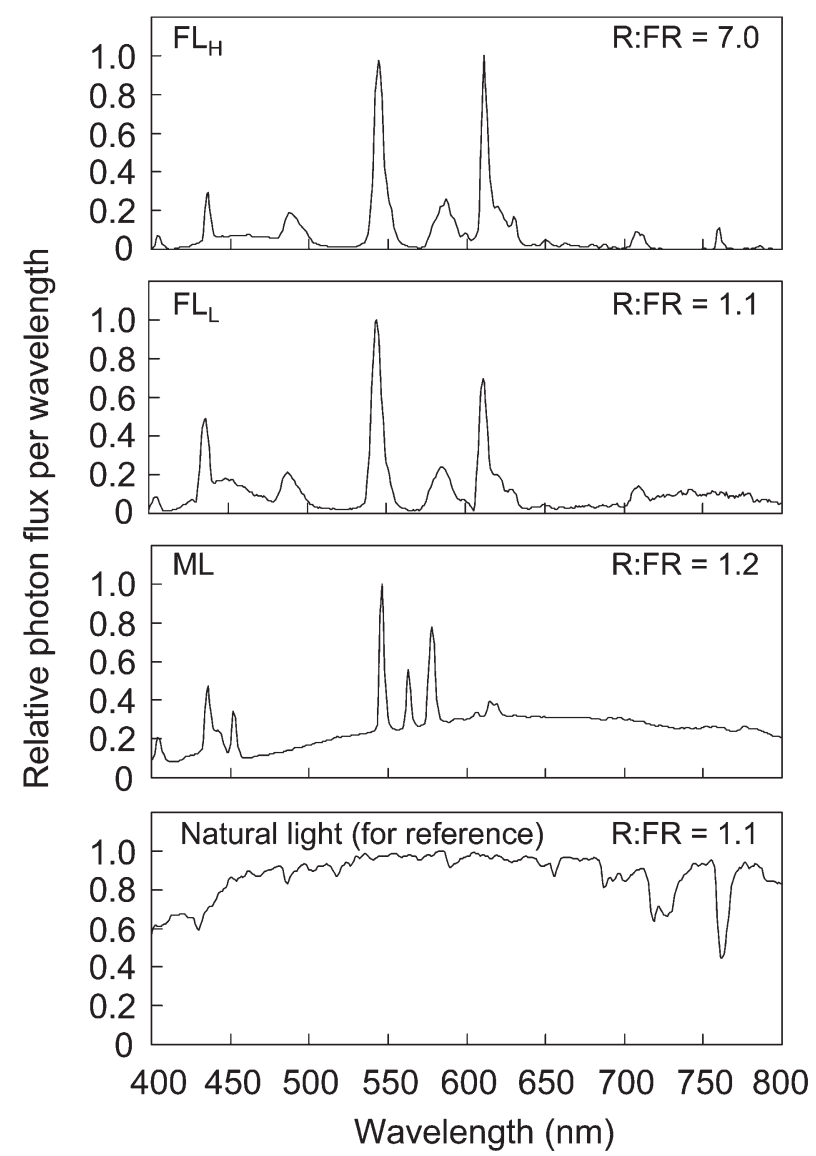

Fig. 1. Fluorescent lamp with high red:far-red $(\mathrm{R}: \mathrm{FR})$ light $\left(\mathrm{FL}_{\mathrm{H}}\right)$, fluorescent lamp with low R:FR light $\left(\mathrm{FL}_{\mathrm{L}}\right)$, and metal-halide lamp (ML) spectra used in the experiment. Photon fluxes per unit wavelength are expressed in values relative to a maximum. R:FR was estimated by dividing the accumulated photon flux from red (wavelength 600 to $700 \mathrm{~nm}$ ) by that from far-red (700 to $800 \mathrm{~nm}$ ) light. The spectrum of ML was measured below the water filter.
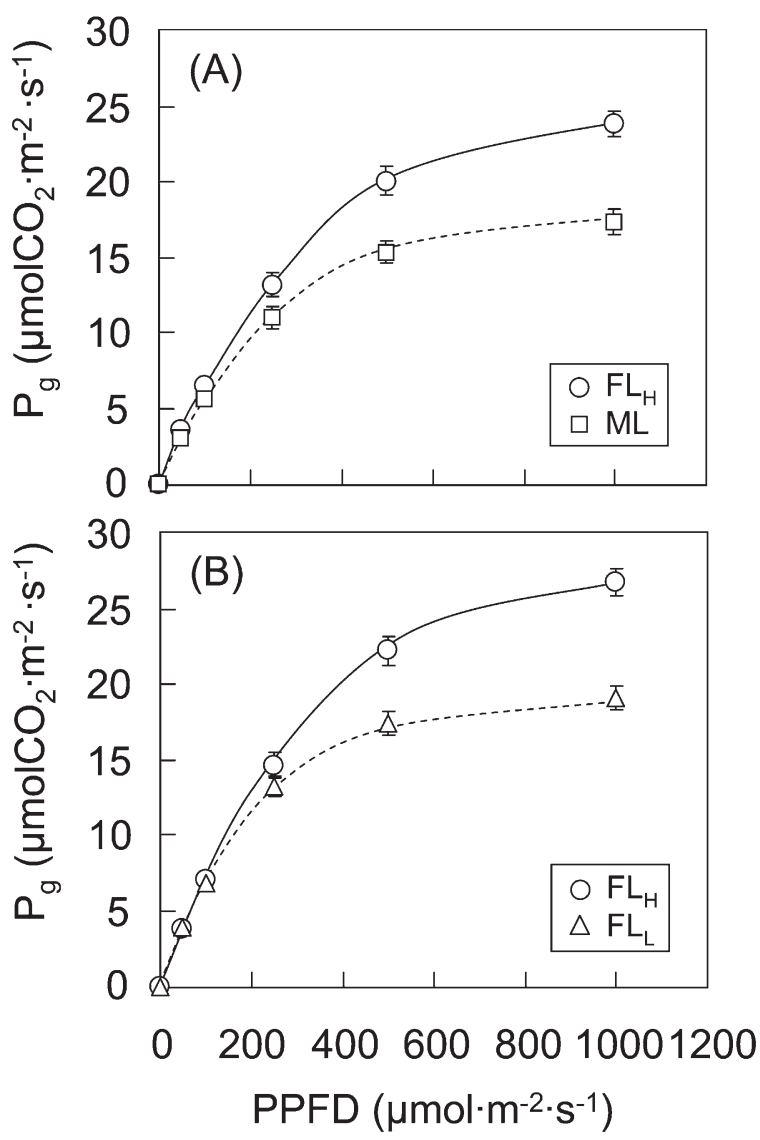

Fig. 2. Light-response curves of gross photosynthetic rate $\left(P_{g}\right)$ of $(\mathbf{A})$ cucumber seedlings grown under fluorescent lamps with high red:far-red (R:FR) light $\left(\mathrm{FL}_{\mathrm{H}}\right.$ ) or metal-halide lamps (ML) (Expt. 1); and (B) those grown under $\mathrm{FL}_{\mathrm{H}}$ or fluorescent lamps with low R:FR light $\left(\mathrm{FL}_{\mathrm{L}}\right)$ (Expt. 2). Values represent means $\pm \mathrm{SE}(\mathrm{n}=5)$. Measurements were conducted at a leaf temperature of $28{ }^{\circ} \mathrm{C}$ and a $\mathrm{CO}_{2}$ concentration of $400 \mu \mathrm{mol} \cdot \mathrm{mol}^{-1}$. Illumination was supplied by red and blue light-emitting diodes in a combination ratio of 9:1 during the measurement. foliage leaf, one unexpanded foliage leaf, and two cotyledons. $P_{n}$ and $\Phi_{\text {PSII }}$ of the first foliage leaves were measured with a photosynthesis and fluorescence measuring system (LI-6400-40; LI-COR Inc., Lincoln, NE) at PPFDs of $1000,500,250,100$, and 50 $\mu \mathrm{mol} \cdot \mathrm{m}^{-2} \cdot \mathrm{s}^{-1}$; the $P P F D$ was changed in the order of high to low. After the measurement of $P_{n}$ and $\Phi_{\text {PSII }}$, the dark respiration rate of the leaves was measured with the same system at a PPFD of $0 \mu \mathrm{mol} \cdot \mathrm{m}^{-2} \cdot \mathrm{s}^{-1}$. Gross photosynthetic rate $\left(\mathrm{P}_{\mathrm{g}}\right)$ was estimated by summing the dark respiration rate and the $P_{n}$. The minimum waiting time for measurement at each $P P F D$ was $3 \mathrm{~min}$, and the maximum was 10 min. Illumination was supplied by red $($ peak $=635 \mathrm{~nm})$ and blue $($ peak $=465 \mathrm{~nm})$ light-emitting diodes in a combination ratio of $9: 1$. In the leaf chamber of the measuring system, the air temperature was maintained at $30 \pm 3{ }^{\circ} \mathrm{C}$, leaf temperature at $28^{\circ} \mathrm{C}$, relative humidity at $50 \% \pm 10 \%$, and $\mathrm{CO}_{2}$ concentration at $400 \mu \mathrm{mol} \cdot \mathrm{mol}^{-1}$. The photosynthetic electron transport rate (ETR) was then estimated from $\Phi_{\text {PSII }}, P P F D$, and leaf absorption in accordance with the method of Genty et al. (1989). The absorbance of leaves was estimated from a relative chlorophyll content determined with a chlorophyll meter (SPAD502; Konica Minolta Sensing Inc., Sakai, Japan) as follows. The relative chlorophyll content of several seedlings' leaves was evaluated with the chlorophyll meter in a preliminary experiment. Absorbance of the leaves was also evaluated from spectral reflectance and transmittance determined with the spectrometer. From these values, the linear relationship between relative chlorophyll content and leaf absorption was determined. Finally, we could estimate the absorbance of sampled leaves from the relative chlorophyll content with this relationship. The measurements of the photosynthetic parameters were conducted for five seedlings in each treatment without replication.

Samples of 10 seedlings in each treatment group were taken to measure the fresh weight, area, and chlorophyll content of the first foliage leaf and the shoot length. The relative chlorophyll content was evaluated with the chlorophyll meter. Fresh weight per leaf area was estimated as an index of leaf thickness. Significance between means of the growth parameters was determined by Student's $t$ test at $P=0.05$ and 0.01 .

Expt. 2: Comparison of high red:far-red fluorescent lamps with low red:far-red fluorescent lamps. Cucumber seedlings were grown in growth chambers illuminated with $\mathrm{FL}_{\mathrm{H}}$ or fluorescent lamps with low R:FR light (FL20S.FR.P; Panasonic Corp.) (FL $\mathrm{F}_{\mathrm{L}}$, and then the photosynthetic light-response curve and growth characteristics of the seedlings were evaluated in the same way as Expt. 1. The spectrum of $\mathrm{FL}_{\mathrm{H}}$ was similar to that of $\mathrm{FL}_{\mathrm{L}}$, except that there was higher photon flux at FR (Fig. 1). The R:FR of $\mathrm{FL}_{\mathrm{L}}$ was 1.1. The growing conditions (with the exception of the light source) and measuring methods were the same as in Expt. 1. It took $6 \mathrm{~d}$ under $\mathrm{FL}_{\mathrm{L}}$ and $8 \mathrm{~d}$ under $\mathrm{FL}_{\mathrm{H}}$ for seedlings to reach an equal growth stage for measurement.

Expt. 3: Effects of seedlings' age on net photosynthetic rate at high photosynthetic photon flux density. We evaluated $\mathrm{P}_{\mathrm{n}}$ of seedlings at varied age to prove that the difference in age of seedlings does not affect the photosynthetic light response. The seedlings was grown under $\mathrm{FL}_{\mathrm{H}}$ or $\mathrm{FL}_{\mathrm{L}}$ for 4,6 , and $8 \mathrm{~d}$ after the cotyledons had fully expanded, and then $P_{n}$ of them was measured at a PPFD of $1000 \mu \mathrm{mol} \cdot \mathrm{m}^{-2} \cdot \mathrm{s}^{-1}$. Measuring methods and conditions (with the exception of $P P F D$ level) were the same as in Expt. 1. 

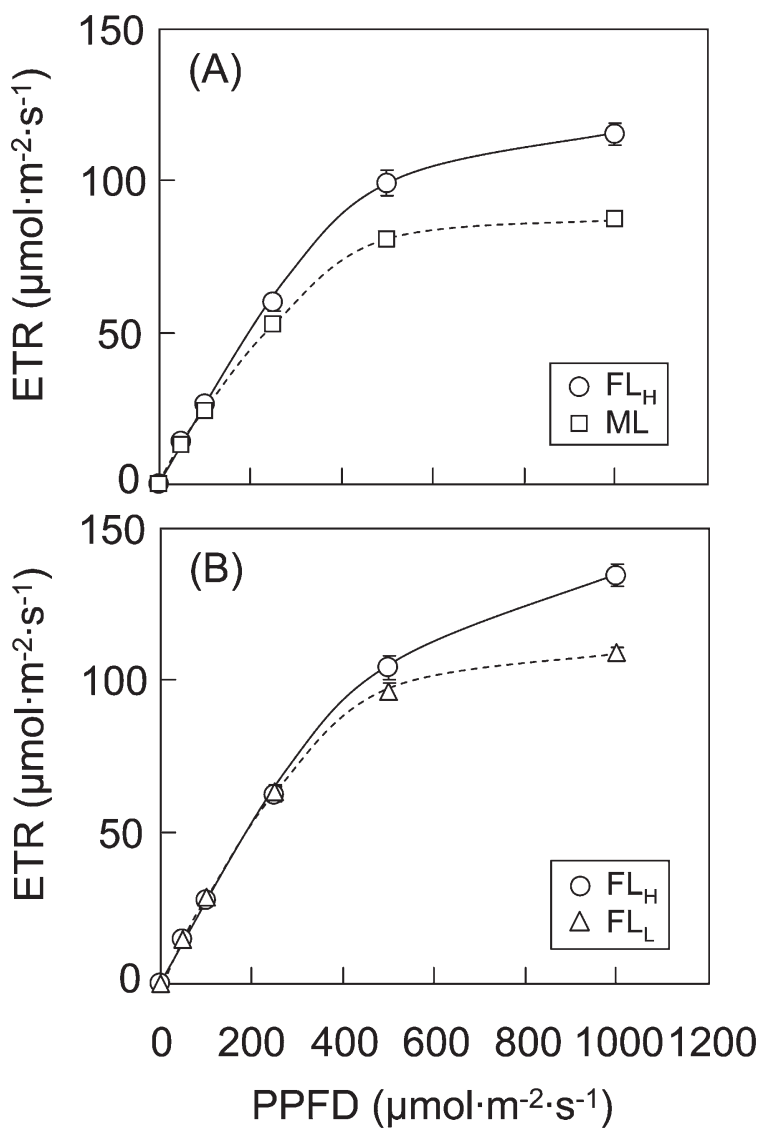

Fig. 3. Light-response curves of photosynthetic electron transfer rate (ETR) of (A) cucumber seedlings grown under fluorescent lamps with high red:far-red (R:FR) light $\left(\mathrm{FL}_{\mathrm{H}}\right)$ or metal-halide lamps (ML) (Expt. $1)$; and $(\mathbf{B})$ those grown under $\mathrm{FL}_{\mathrm{H}}$ or fluorescent lamps with low R:FR light $\left(\mathrm{FL}_{\mathrm{L}}\right)$ (Expt. 2). Values represent means $\pm \mathrm{SE}(\mathrm{n}=5)$. For measurement conditions, see Figure 2.
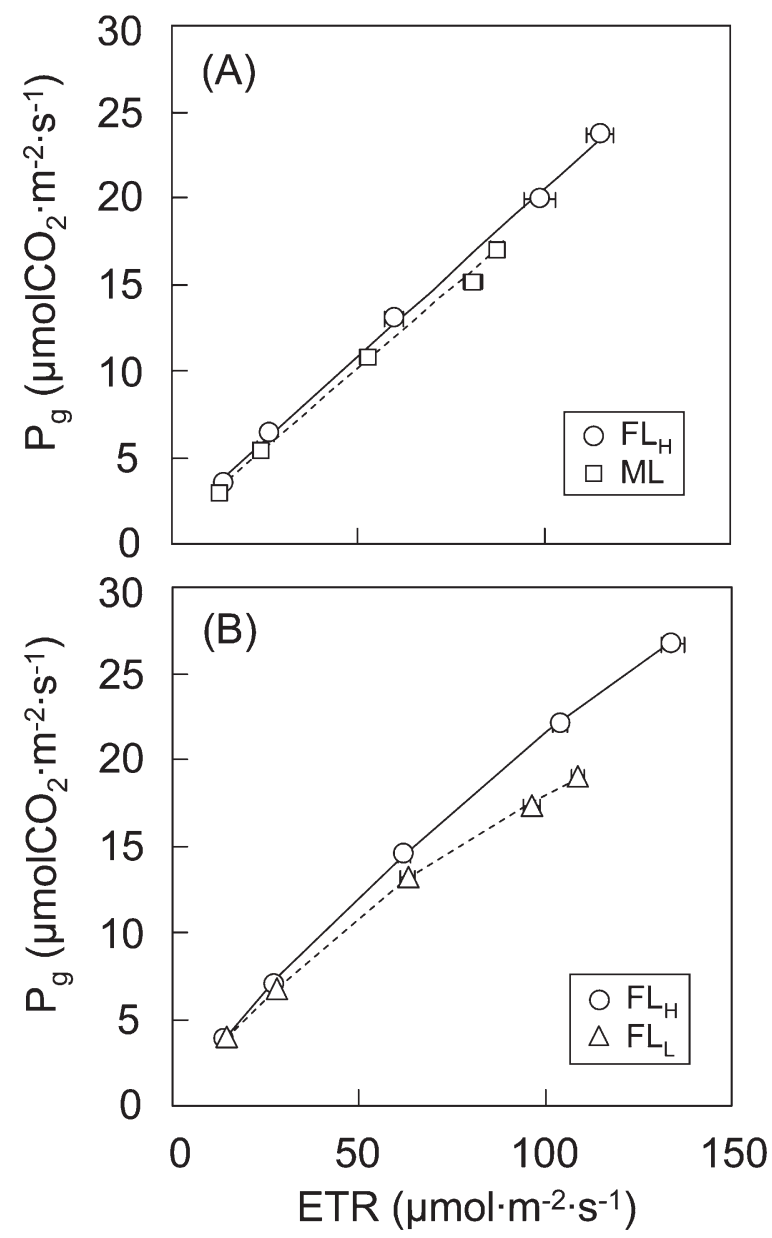

Fig. 4. Relationships between photosynthetic electron transfer rate (ETR) and gross photosynthetic rate $\left(\mathrm{P}_{\mathrm{g}}\right)$ of $(\mathbf{A})$ cucumber seedlings grown under fluorescent lamps with high red:far-red $(\mathrm{R}: \mathrm{FR})$ light $\left(\mathrm{FL}_{\mathrm{H}}\right)$ or metal-halide lamps (ML) (Expt. 1); and (B) those grown under $\mathrm{FL}_{\mathrm{H}}$ or fluorescent lamps with low R:FR light $\left(\mathrm{FL}_{\mathrm{L}}\right)$ (Expt. 2). Values represent means $\pm \operatorname{SE}(\mathrm{n}=5)$.

\section{Results}

Expt. 1. The $\mathrm{P}_{\mathrm{g}}$ of seedlings grown under either $\mathrm{FL}_{\mathrm{H}}$ or ML increased with a tendency of saturation as $P P F D$ was raised from 0 to $1000 \mu \mathrm{mol} \cdot \mathrm{m}^{-2} \cdot \mathrm{s}^{-1}$ (Fig. 2A). The tendency of saturation was stronger in $\mathrm{ML}$ than $\mathrm{FL}_{\mathrm{H}}$. The $\mathrm{P}_{\mathrm{g}}$ of $\mathrm{FL}_{\mathrm{H}}$ seedlings was $1.18,1.15,1.20$, 1.31 , and 1.38 times that of ML seedlings at PPFDs of 50, 100, 250, 500, and 1000 $\mu \mathrm{mol} \cdot \mathrm{m}^{-2} \cdot \mathrm{s}^{-1}$, respectively. The light compensation point, estimated from the lightresponse curve of $\mathrm{P}_{\mathrm{n}}$ (data not shown), was $35 \mu \mathrm{mol} \cdot \mathrm{m}^{-2} \cdot \mathrm{s}^{-1}$ in $\mathrm{FL}_{\mathrm{H}}$ seedlings and 33 $\mu \mathrm{mol} \cdot \mathrm{m}^{-2} \cdot \mathrm{s}^{-1}$ in $\mathrm{ML}$ seedlings. The ratio of $\mathrm{P}_{\mathrm{g}}$ of the $\mathrm{FL}_{\mathrm{H}}$ seedlings to that of the ML seedlings increased with increasing $P P F D$. The ETR of seedlings grown under $\mathrm{FL}_{\mathrm{H}}$ or ML increased with increasing $P P F D$ from 0 to $1000 \mu \mathrm{mol} \cdot \mathrm{m}^{-2} \cdot \mathrm{s}^{-1}$ in the same way as $\mathrm{P}_{\mathrm{g}}$ (Fig. 3A). The ETR of $\mathrm{FL}_{\mathrm{H}}$ seedlings was $1.08,1.10,1.14,1.22$, and 1.32 times that of ML seedlings at PPFDs of 50,100, 250, 500, and $1000 \mu \mathrm{mol} \cdot \mathrm{m}^{-2} \cdot \mathrm{s}^{-1}$, respectively. An almost linear relationship between ETR and $P_{g}$ was observed in each treatment group (Fig. 4A). The $\mathrm{P}_{\mathrm{g}}$ in ML seedlings tended to be lower than in $\mathrm{FL}_{\mathrm{H}}$ seedlings at the same ETR. The $\Phi_{\text {PSII }}$ of $\mathrm{FL}_{\mathrm{H}}$ seedlings was 1.05 , $1.07,1.11,1.19$, and 1.28 times that of ML seedlings at PPFDs of 50,100,250, 500, and $1000 \mu \mathrm{mol} \cdot \mathrm{m}^{-2} \cdot \mathrm{s}^{-1}$, respectively (Fig. $5 \mathrm{~A}$ ). The ratio of the $\Phi_{\text {PSII }}$ of the $\mathrm{FL}_{\mathrm{H}}$ seedlings to those of the ML seedlings increased with increasing $P P F D$. There was no significant difference in leaf fresh weight or leaf area between $\mathrm{FL}_{\mathrm{H}}$ and ML seedlings $(P>0.05$; Table 1). The fresh weight per leaf area, relative chlorophyll content, and shoot length in $\mathrm{FL}_{\mathrm{H}}$ seedlings were $1.11,1.25$, and 0.47 times, respectively, those of ML seedlings $(P<0.01$; Table 1$)$. The absorbance of red and blue mixed light in $\mathrm{FL}_{\mathrm{H}}$ leaves was $89.4 \%$ and that in ML leaves was $86.9 \%$.

Expt. 2. The ETR and $\Phi_{\text {PSII }}$ of $\mathrm{FL}_{\mathrm{H}}$ seedlings in Expt. 2 were greater than those in Expt. 1 (Figs. 3 and 5), although the environmental conditions were almost the same for $\mathrm{FL}_{\mathrm{H}}$ seedlings in the two experiments. The growth parameters of $\mathrm{FL}_{\mathrm{H}}$ seedlings in each experiment also differed (Tables 1 and 2). These differences were probably the result of differences in the timing of the experiment, although the true reasons are not clear. The absolute values obtained in each experiment could not be compared directly.

The $\mathrm{P}_{\mathrm{g}}$ of seedlings grown under either $\mathrm{FL}_{\mathrm{H}}$ or $\mathrm{FL}_{\mathrm{L}}$ increased with a tendency of saturation as $P P F D$ was raised from 0 to $1000 \mu \mathrm{mol} \cdot \mathrm{m}^{-2} \cdot \mathrm{s}^{-1}$ (Fig. 2B). The tendency of saturation is stronger in $\mathrm{FL}_{\mathrm{L}}$ than $\mathrm{FL}_{\mathrm{H}}$. The ratio of the $\mathrm{P}_{\mathrm{g}}$ of the $\mathrm{FL}_{\mathrm{H}}$ seedlings to that of the $\mathrm{FL}_{\mathrm{L}}$ seedlings increased with increasing $P P F D$ in the same way as the relationship between $\mathrm{FL}_{\mathrm{H}}$ and ML in Expt. 1. The $\mathrm{P}_{\mathrm{g}}$ of $\mathrm{FL}_{\mathrm{H}}$ seedlings was $0.97,1.04,1.11,1.28$, and 1.40 times that of $\mathrm{FL}_{\mathrm{L}}$ seedlings at $P P F D$ s of $50,100,250,500$, and $1000 \mu \mathrm{mol} \cdot \mathrm{m}^{-2} \cdot \mathrm{s}^{-1}$, respectively. The light compensation point, estimated from the light-response curve of $\mathrm{P}_{n}$ (data not shown), was $50 \mu \mathrm{mol} \cdot \mathrm{m}^{-2} \cdot \mathrm{s}^{-1}$ in $\mathrm{FL}_{\mathrm{H}}$ seedlings and $47 \mu \mathrm{mol} \cdot \mathrm{m}^{-2} \cdot \mathrm{s}^{-1}$ in $\mathrm{FL}_{\mathrm{L}}$ seedlings. The ETR of seedlings grown under $\mathrm{FL}_{\mathrm{H}}$ or $\mathrm{FL}_{\mathrm{L}}$ increased with increasing $P P F D$ from 0 to $1000 \mu \mathrm{mol} \cdot \mathrm{m}^{-2} \cdot \mathrm{s}^{-1}$ in the same way as $\mathrm{P}_{\mathrm{g}}$ (Fig. 3B). A strong correlation was observed between ETR and $P_{g}$ in each treatment group (Fig. 4B). $\mathrm{P}_{\mathrm{g}}$ increased linearly with ETR; however, the slope became gentler in $\mathrm{FL}_{\mathrm{L}}$ seedlings at higher ETR, whereas it was almost constant in $\mathrm{FL}_{\mathrm{H}}$ seedlings. 
The $\mathrm{P}_{\mathrm{g}}$ in $\mathrm{FL}_{\mathrm{L}}$ seedlings was lower than in $\mathrm{FL}_{\mathrm{H}}$ seedlings at high ETRs (from $\approx 100$ $\left.\mu \mathrm{mol} \cdot \mathrm{m}^{-2} \cdot \mathrm{s}^{-1}\right)$. The $\Phi_{\mathrm{PSII}}$ of $\mathrm{FL}_{\mathrm{H}}$ seedlings was greater than that of $\mathrm{FL}_{\mathrm{L}}$ seedlings at PPFDs of 500 and $1000 \mu \mathrm{mol} \cdot \mathrm{m}^{-2} \cdot \mathrm{s}^{-1}$ but smaller than that of $\mathrm{FL}_{\mathrm{L}}$ seedlings at PPFDs of 50 and $100 \mu \mathrm{mol} \cdot \mathrm{m}^{-2} \cdot \mathrm{s}^{-1}$ (Fig. 5B). The ratios of the ETR and $\Phi_{\mathrm{PSII}}$ of $\mathrm{FL}_{\mathrm{H}}$ seedlings to those of $\mathrm{FL}_{\mathrm{L}}$ seedlings increased with increasing PPFD in the same way as these ratios for $\mathrm{FL}_{\mathrm{H}}$ to $\mathrm{ML}$ in Expt. 1. The relationships between the photosynthetic light response of $\mathrm{FL}_{\mathrm{H}}$ and $\mathrm{FL}_{\mathrm{L}}$ were therefore similar to those of $\mathrm{FL}_{\mathrm{H}}$ and ML in Expt. 1, but ETR and $\Phi_{\text {PSII }}$ of $\mathrm{FL}_{\mathrm{H}}$ were greater than in Expt. 1.

There were no significant differences in leaf fresh weight and leaf area between $\mathrm{FL}_{\mathrm{H}}$ and $\mathrm{FL}_{\mathrm{L}}$ seedlings $(P>0.05$; Table 2$)$. The fresh weight per leaf area in $\mathrm{FL}_{\mathrm{H}}$ seedlings was 1.09 times that in $\mathrm{FL}_{\mathrm{L}}$ seedlings $(P<$ 0.05 ; Table 2). The relative chlorophyll content and shoot length in $\mathrm{FL}_{\mathrm{H}}$ seedlings were 1.28 and 0.56 times, respectively, those in $\mathrm{FL}_{\mathrm{L}}$ seedlings $(P<0.01$; Table 2$)$. The relationship between the growth characteristics of $\mathrm{FL}_{\mathrm{H}}$ and $\mathrm{FL}_{\mathrm{L}}$ were therefore similar to those of $\mathrm{FL}_{\mathrm{H}}$ and ML in Expt. 1, but the growth parameters of $\mathrm{FL}_{\mathrm{H}}$ seedlings were greater than in Expt. 1. The absorbance of red and blue mixed light in $\mathrm{FL}_{\mathrm{H}}$ leaves was $90.0 \%$ and that in $\mathrm{FL}_{\mathrm{L}}$ leaves was $89.6 \%$.

Expt. 3. The $\mathrm{P}_{\mathrm{n}}$ of seedlings grown under either $\mathrm{FL}_{\mathrm{H}}$ or ML was increased from Day 4 to Day 6 and then was maintained almost constant from Day 6 to Day 8 (Fig. 6). The $\mathrm{P}_{\mathrm{n}}$ of $\mathrm{FL}_{\mathrm{H}}$ seedlings was greater than those of $\mathrm{FL}_{\mathrm{L}}$ regardless of their age and was $\approx 1.2$ times those of $\mathrm{FL}_{\mathrm{L}}$ at the same age. The $\mathrm{P}_{\mathrm{n}}$ in this experiment was greater than those in Expt. 2 (data not shown).

\section{Discussion}

The differences in the photosynthetic light response and morphological characteristics between $\mathrm{FL}_{\mathrm{H}}$ and ML seedlings seemed to be the result of the difference in R:FR between the two lamps because similar relationships were observed between $\mathrm{FL}_{\mathrm{H}}$ and $\mathrm{FL}_{\mathrm{L}}$ in Expt. 2 in which virtually only the FR photon flux was modified.

The $\mathrm{FL}_{\mathrm{H}}$ seedlings took $2 \mathrm{~d}$ longer $(8 \mathrm{~d})$ to equal the growth stage of ML or $\mathrm{FL}_{\mathrm{L}}$ seedlings for measurement. This difference in age of seedlings probably did not affect their photosynthetic light response because the $\mathrm{P}_{\mathrm{n}}$ of $\mathrm{FL}_{\mathrm{H}}$ seedlings at high PPFD on Day 6 and Day 8 was almost same and was greater than those of $\mathrm{FL}_{\mathrm{L}}$ seedlings at the same age (Fig. 6). However, why the $P_{n}$ in Expt. 3 was greater than those in Expt. 2 is unknown.

Comparison with the results of another experiment revealed that the photosynthetic light response of $\mathrm{FL}_{\mathrm{H}}$ seedlings was similar to those of sun leaves, and the curves of ML and $\mathrm{FL}_{\mathrm{L}}$ seedlings were similar to those of shade leaves (Lichtenthaler et al., 1981); photosynthetic light-use efficiency at high PPFDs was higher in $\mathrm{FL}_{\mathrm{H}}$ seedlings than in $\mathrm{ML}$ and $\mathrm{FL}_{\mathrm{L}}$ seedlings grown at the same PPFDs (Fig. 2).
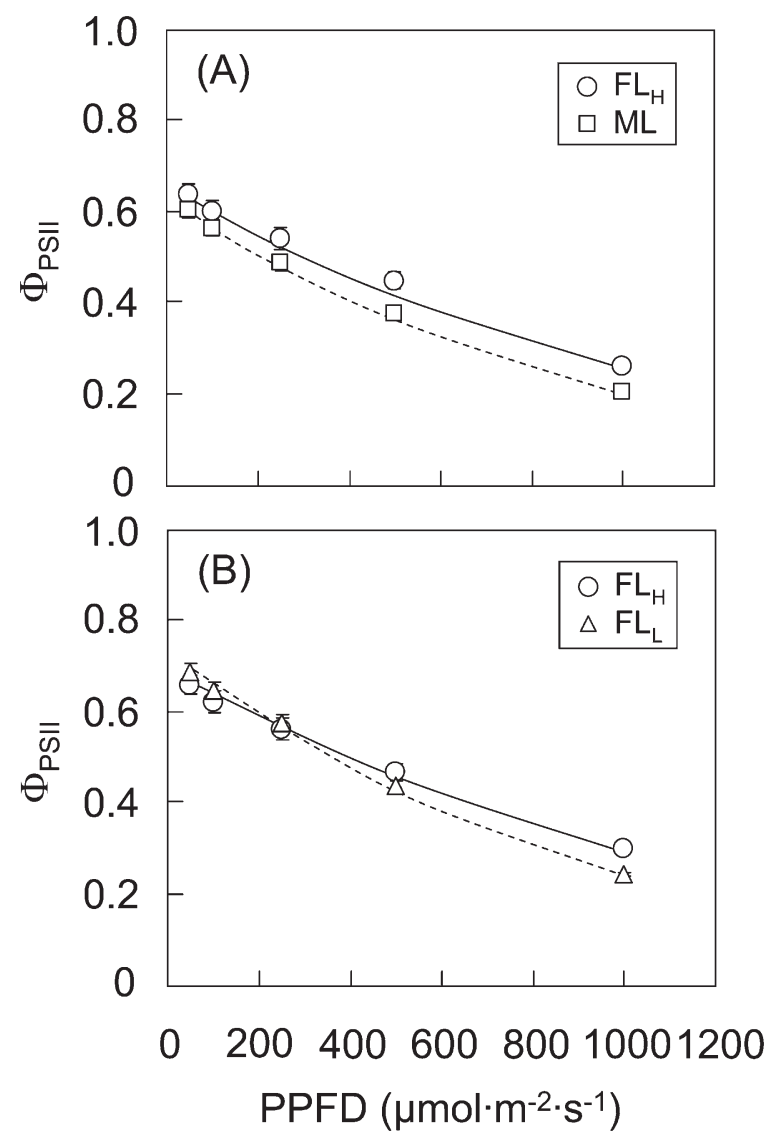

Fig. 5. Light-response curves of quantum yield of photosystem II ( $\left.\Phi_{\mathrm{PSII}}\right)$ of $(\mathbf{A})$ cucumber seedlings grown under fluorescent lamps with high red:far-red (R:FR) light $\left(\mathrm{FL}_{\mathrm{H}}\right)$ or metal-halide lamps (ML) (Expt. 1); and (B) those grown under $\mathrm{FL}_{\mathrm{H}}$ or fluorescent lamps with low R:FR light (FL $\mathrm{L}_{\mathrm{L}}$ (Expt. 2). Values represent means $\pm \operatorname{SE}(n=5)$. For measurement conditions, see Figure 2.

Table 1. Leaf fresh weight, leaf area, relative chlorophyll content of first leaf, and shoot length in cucumber seedlings grown under fluorescent lamps with high red:far-red light $\left(\mathrm{FL}_{\mathrm{H}}\right)$ or metal-halide lamps $(\mathrm{ML})$ (Expt. 1).

\begin{tabular}{|c|c|c|c|c|c|}
\hline Treatment & $\begin{array}{c}\text { Leaf fresh } \\
\text { wt (mg) }\end{array}$ & $\begin{array}{l}\text { Leaf area } \\
\left(\mathrm{cm}^{2}\right)\end{array}$ & $\begin{array}{c}\text { Fresh wt per } \\
\text { leaf area } \\
\left(\mathrm{mg} \cdot \mathrm{cm}^{-2}\right)\end{array}$ & $\begin{array}{c}\text { Relative } \\
\text { chlorophyll } \\
\text { content } \\
\text { (SPAD value) }\end{array}$ & $\begin{array}{l}\text { Shoot length } \\
(\mathrm{mm})\end{array}$ \\
\hline$\overline{\mathrm{FL}_{\mathrm{H}}}$ & $509 \pm 14$ & $28.6 \pm 0.6$ & $17.8 \pm 0.3$ & $38.7 \pm 0.5$ & $31.2 \pm 2.9$ \\
\hline $\mathrm{ML}$ & $475 \pm 11$ & $29.6 \pm 0.6$ & $16.1 \pm 0.1$ & $30.9 \pm 0.5$ & $67.0 \pm 3.7$ \\
\hline Significance & NS & NS & $* *$ & $* *$ & $* *$ \\
\hline
\end{tabular}

Values are means \pm SE $(n=10)$. Relative chlorophyll content was the chlorophyll meter value (SPAD-502; Konica Minolta Sensing Inc., Sakai, Japan).

NS $=$ nonsignificant at $P=0.05$; **significantly different between the treatments at $P=0.01$, respectively, according to Student's $t$ test.

Table 2. Leaf fresh weight, leaf area, relative chlorophyll content of first leaf, and shoot length in cucumber seedlings grown under fluorescent lamps with high red:far-red (R:FR) light $\left(\mathrm{FL}_{\mathrm{H}}\right)$ or fluorescent lamps with low R:FR light (FL $\left.{ }_{\mathrm{L}}\right)$ (Expt. 2).

\begin{tabular}{lccccc}
\hline & & & Relative & \\
Treatment & $\begin{array}{c}\text { Leaf fresh } \\
\text { wt }(\mathrm{mg})\end{array}$ & $\begin{array}{c}\text { Leaf area } \\
\left(\mathrm{cm}^{2}\right)\end{array}$ & $\begin{array}{c}\text { leaf area } \\
\left(\mathrm{mg} \cdot \mathrm{cm}^{-2}\right)\end{array}$ & $\begin{array}{c}\text { conlophyll } \\
\text { content } \\
(\text { SPAD value })\end{array}$ & $\begin{array}{c}\text { Shoot length } \\
(\mathrm{mm})\end{array}$ \\
\hline $\mathrm{FL}_{\mathrm{H}}$ & $810 \pm 23$ & $40.5 \pm 1.9$ & $20.2 \pm 0.6$ & $43.1 \pm 1.1$ & $33.5 \pm 1.1$ \\
$\mathrm{FL}_{\mathrm{L}}$ & $759 \pm 23$ & $39.4 \pm 1.0$ & $18.6 \pm 0.4$ & $33.8 \pm 1.5$ & $60.1 \pm 2.0$ \\
Significance & NS & NS & $*$ & $* *$ & $* *$ \\
\hline
\end{tabular}

Values are means \pm SE $(n=10)$. Relative chlorophyll content was the chlorophyll meter value (SPAD-502; Konica Minolta Sensing Inc., Sakai, Japan).

NS $=$ nonsignificant at $P=0.05 ; *$ and ** significantly different between the treatments at $P=0.05$ and $P=$ 0.01 , respectively, according to Student's $t$ test.

This means that, at high PPFDs, seedlings grown in a closed system under $\mathrm{FL}_{\mathrm{H}}$ would fix more $\mathrm{CO}_{2}$ per leaf area than seedlings grown under natural light at the same $P P F D$.
In contrast, a low PPFD would be unfavorable to $\mathrm{FL}_{\mathrm{H}}$ seedlings because, like in sun leaves versus shade leaves, the light compensation point of $\mathrm{FL}_{\mathrm{H}}$ seedlings was higher than 


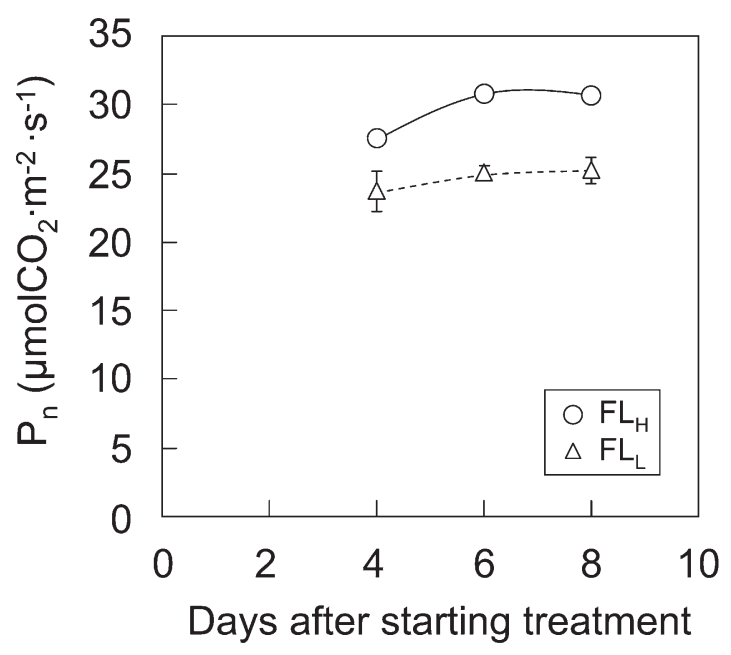

Fig. 6. Changes in net photosynthetic rate $\left(\mathrm{P}_{\mathrm{n}}\right)$ of cucumber seedlings grown under fluorescent lamps with high red:far-red (R:FR) light $\left(\mathrm{FL}_{\mathrm{H}}\right)$ or fluorescent lamps with low R:FR light $\left(\mathrm{FL}_{\mathrm{L}}\right)$ after starting treatment (Expt. 3). Values represent means $\pm \mathrm{SE}$ (Day 4, $\mathrm{n}=5$; Day $6, \mathrm{n}=4$; Day 8, $\mathrm{FL}_{\mathrm{H}}: \mathrm{n}=5, \mathrm{FL}_{\mathrm{L}}: \mathrm{n}=$ 4). Measurements were conducted at a photosynthetic photon flux density of $1000 \mu \mathrm{mol} \cdot \mathrm{m}^{-2} \cdot \mathrm{s}^{-1}$, a leaf temperature of $28^{\circ} \mathrm{C}$, and a $\mathrm{CO}_{2}$ concentration of $400 \mu \mathrm{mol} \cdot \mathrm{mol}^{-1}$. Illumination was supplied by red and blue light-emitting diodes in a combination ratio of 9:1 during the measurement.

those of ML and $\mathrm{FL}_{\mathrm{L}}$ seedlings. Illumination with low R:FR light is advantageous for improving the growth of seedlings because plants often grow faster at lower R:FR (Murakami et al., 1991; Pausch et al., 1991), as we also observed here. On the other hand, the photosynthetic efficiency in $\mathrm{FL}_{\mathrm{H}}$ seedlings was greater than that in $\mathrm{FL}_{\mathrm{L}}$ seedlings at high PPFDs, although the growth rate in the former was lower. Therefore, a high R:FR light is probably advantageous when seedlings are to be moved to high $P P F D$ conditions, for example, as transplants. There is, therefore, a tradeoff between faster growth and improved photosynthetic efficiency at high PPFDs. In selecting artificial light for plant production, we need to consider which of the two advantages is more important.

The higher $\mathrm{P}_{\mathrm{g}}$ of $\mathrm{FL}_{\mathrm{H}}$ seedlings at high PPFDs was probably the result of the higher ETR, because $\mathrm{P}_{\mathrm{g}}$ was closely correlated with ETR (Fig. 4). One reason for the higher ETR of $\mathrm{FL}_{\mathrm{H}}$ seedlings than of $\mathrm{ML}$ and $\mathrm{FL}_{\mathrm{L}}$ seedlings was the higher relative chlorophyll content per leaf area. Another reason is probably the higher efficiency of PSII photochemistry in $\mathrm{FL}_{\mathrm{H}}$ seedlings than in $\mathrm{ML}$ seedlings and in $\mathrm{FL}_{\mathrm{L}}$ seedlings at high PPFDs (Fig. 5). The function of chlorophyll may differ with the R:FR in the same way as it differs in sun and shade leaves (Öquist et al., 1992). However, we do not know the reason for the improved $\Phi_{\mathrm{PSII}}$ in $\mathrm{FL}_{\mathrm{H}}$ seedlings compared with $\mathrm{ML}$ and $\mathrm{FL}_{\mathrm{L}}$ seedlings at high PPFDs (Fig. 5). A linear relationship between ETR and $P_{g}$ was observed over a wide range of them in Expt. 1, meaning that $\mathrm{CO}_{2}$ fixation efficiency per electron transport remained constant. The efficiency of $\mathrm{CO}_{2}$ fixation in $\mathrm{C}_{3}$ plants is reduced because of photorespiration when $\mathrm{CO}_{2}$ fixation is saturated (Kato et al., 2003). In Expt. 1 , strong nonphotochemical heat dissipation was probably induced under high $P P F D$; consequently, the linear relationship between
ETR and $\mathrm{P}_{\mathrm{g}}$ was maintained. This would be supported by the decrease in $\Phi_{\text {PSII }}$ under higher PPFD. On the other hand, the development of a nonlinear relationship in Expt. 2 was probably the result of the greater $\mathrm{P}_{\mathrm{g}}$ and ETR than those in Expt. 1. The gentle slope in the relationship between ETR and $\mathrm{P}_{\mathrm{g}}$ in $\mathrm{FL}_{\mathrm{L}}$ seedlings at high ETR (Fig. 4B) seemed to be the result of the reduction of the $\mathrm{CO}_{2}$ fixation efficiency at a high $P P F D$. The reduction of $\mathrm{CO}_{2}$ fixation efficiency could also be reduced by acclimating to high PPFD (Kato et al., 2003). Our results suggest that both a high R:FR light and high PPFD act by the same mechanism to reduce the reduction of $\mathrm{CO}_{2}$ fixation efficiency. To clarify these mechanisms, a detailed analysis of chlorophyll function will be necessary.

From the values of fresh weight per leaf area and relative chlorophyll content (Tables 1 and 2), we assumed that leaf thickness and chlorophyll content per leaf area were greater in growth under $\mathrm{FL}_{\mathrm{H}}$ than under $\mathrm{ML}$ or $\mathrm{FL}_{\mathrm{L}}$. The R:FR under $\mathrm{FL}_{\mathrm{H}}$ (7.0) is much higher than that of solar radiation and does not exist in nature. With a lower R:FR than occurs with natural light, shoot elongation and leaf expansion rates increase so that the plant can avoid shade and chlorophyll content declines (Smith and Whitelam, 1997). In addition, plant leaves adapted to low R:FR light have low net photosynthetic rates (Maliakal et al., 1999; Sleeman and Dudley, 2001; Sleeman et al. 2002). In $\mathrm{FL}_{\mathrm{H}}$ seedlings, the inverse physiological and morphological responses (i.e., increased leaf thickness and chlorophyll content and reduced shoot elongation) to those typical of shade avoidance seemed to be the result of heightened adaptation to the higher $P P F D$ induced by the high R:FR of $\mathrm{FL}_{\mathrm{H}}$. The photosynthetic efficiency of $\mathrm{FL}_{\mathrm{H}}$ seedlings at high PPFDs was probably improved as a result of this heightened adaptation to sun.
From these data, we concluded that growth of cucumber seedlings under fluorescent lamps with high R:FR light can improve potential photosynthesis compared with that under low R:FR illumination. Photosynthetic responses under light of different qualities have been well investigated (Goins et al., 1997; Korbee et al., 2005; Pausch et al., 1991; Yorio et al., 2001). The fact that light quality affects photosynthetic light response should be considered in selecting a light source for plant production under artificial light when postproduction characteristics are vital such as in transplant production.

\section{Literature Cited}

Corré, W.J. 1983. Growth and morphogenesis of sun and shade plants. II. The influence of light quality. Acta Bot. Neerl. 32:185-202.

Franklin, K.A. 2008. Shade avoidance. New Phytol. 179:930-944.

Genty, B., J.M. Briantais, and N.R. Baker. 1989. The relationship between quantum yield of photosynthetic electron transport and quenching of chlorophyll fluorescence. Biochim. Biophys. Acta 990:87-92.

Goins, G.D., N.C. Yorio, M.M. Sanwo, and C.S. Brown. 1997. Photomorphogenesis, photosynthesis, and seed yield of wheat plants grown under red light-emitting diodes (LEDs) with and without supplemental blue lighting. J. Expt. Bot. 48:1407-1413.

Kato, M.C., K. Hikosaka, N. Hirotsu, A. Makino, and T. Hirose. 2003. The excess light energy that is neither utilized in photosynthesis nor dissipated by photoprotective mechanisms determines the rate of photoinactivation in photosystem II. Plant Cell Physiol. 44:318325.

Korbee, N., F.L. Figueroa, and J. Aguilera. 2005. Effect of light quality on the accumulation of photosynthetic pigments, proteins and mycosporinelike amino acids in the red alga Porphyra leucosticta (Bangiales, Rhodophyta). J. Photochem. Photobiol. B: Biol. 80:71-78.

Kozai, T. 2007. Propagation, grafting and transplant production in closed systems with artificial lighting for commercialization in Japan. Propag. Ornam. Plants 7:145-149.

Kozai, T., K. Ohyama, and C. Chun. 2006. Commercialized closed systems with artificial lighting for plant production. Acta Hort. 711: 61-70.

Lichtenthaler, H.K., C. Buschmann, M. Döll, H.J. Fietz, T. Bach, U. Kozel, D. Meier, and U. Rahmsdorf. 1981. Photosynthetic activity, chloroplast ultrastructure, and leaf characteristics of high-light and low-light plants and of sun and shade leaves. Photosynth. Res. 2:115141.

Maliakal, S., K. McDonnell, S.A. Dudley, and J. Schmitt. 1999. Effects of red to far-red ratio and plant density on biomass allocation and gas exchange in Impatiens capensis. Int. J. Plant Sci. 160:723-733.

Maxwell, K. and G.N. Johnson. 2000. Chlorophyll fluorescence - A practical guide. J. Expt. Bot. 51:659-668.

Murakami, K., K. Horaguchi, M. Morita, and I. Aiga. 1991. Growth control of the sunflower (Helianthus annuus L. cv. Russian Mammoth) seedling by additional far-red irradiation. Environ. Control Biol. 29:73-79 [in Japanese with English summary and captions].

Murchie, E.H. and P. Horton. 1997. Acclimation of photosynthesis to irradiance and spectral 
quality in British plant species: Chlorophyll content, photosynthetic capacity and habitat preference. Plant Cell Environ. 20:438-448.

Ohyama, K., K. Manabe, Y. Omura, C. Kubota, and T. Kozai. 2003. A comparison between closed-type and open-type transplant production systems with respect to quality of tomato plug transplants and resource consumption during summer. Environ. Control Biol. 41:57-61 [in Japanese with English summary and captions].

Öquist, G., J.M. Anderson, S. McCaffery, and W.S. Chow. 1992. Mechanistic differences in photoinhibition of sun and shade plants. Planta 188:422-431.
Pausch, R.C., S.J. Britz, and C.L. Mulchi. 1991. Growth and photosynthesis of soybean [Glycine $\max$ (L.) Merr.] in simulated vegetation shade: Influence of the ratio of red to farred radiation. Plant Cell Environ. 14:647-656.

Sleeman, J.D. and S.A. Dudley. 2001. Effects of light quality on gas exchange and morphological traits in rapid-cycling Brassica rapa. Int. J. Plant Sci. 162:297-307.

Sleeman, J.D., S.A. Dudley, J.R. Pannell, and S.C.H. Barrett. 2002. Responses of carbon acquisition traits to irradiance and light quality in Mercurialis annua (Euphorbiaceae): Evidence for weak integration of plastic responses. Amer. J. Bot. 89:1388-1400.
Smith, H. and G.C. Whitelam. 1997. The shade avoidance syndrome: Multiple responses mediated by multiple phytochromes. Plant Cell Environ. 20:840-844.

Turnbull, M.H., D. Doley, and D.J. Yates. 1993. The dynamics of photosynthetic acclimation to changes in light quantity and quality in three Australian rainforest tree species. Oecologia 94:218-228.

Yorio, N.C., G.D. Goins, H.R. Kagie, R.M Wheeler, and J.C. Sager. 2001. Improving spinach, radish, and lettuce growth under red light-emitting diodes (LEDs) with blue light supplementation. HortScience 36:380383. 